\title{
Pengaruh Jenis Poliol terhadap Pembentukan Poliuretan dari Monomer PEG400 dan MDI
}

\author{
Eli Rohaeti*, N. M. Surdia**, Cynthia L. Radiman** \& E. Ratnaningsih** \\ * Staf Pengajar Jurusan Pendidikan Kimia FMIPA Universitas Negeri Yogyakarta, \\ Kampus Karangmalang Yogyakarta 55281 \\ E-mail: s398eli@mail.chem.itb.ac.id \\ ** Staf Pengajar Departemen Kimia FMIPA Institut Teknologi Bandung, \\ Jl. Ganesa 10 Bandung 40132
}

\begin{abstract}
Sari. Sifat poliuretan tergantung pada blok/monomer penyusunnya, terutama tergantung pada jenis poliol. Tidak hanya senyawa sintetik murni tetapi juga berbagai bahan alam seperti sakarida (glukosa, fruktosa, maltosa, sukrosa) dan amilosa dapat digunakan sebagai sumber poliol dalam sintesis poliuretan. Bahanbahan alam tersebut merupakan bahan polimer alam yang memiliki kereaktifan yang disebabkan oleh gugus fungsi seperti gugus hidroksil yang dimilikinya. Bahan polimer alam yang memiliki gugus hidroksil per molekulnya lebih dari dua dapat digunakan sebagai sumber poliol dalam sintesis poliuretan. Dalam penelitian ini, dipelajari pengaruh penambahan glukosa, maltosa, dan amilosa terhadap pembentukan poliuretan dari polietilen glikol 400 (PEG400) dan metilen-4,4'difenildiisosianat (MDI) melalui pengukuran besarnya indeks ikatan hidrogen (HBI) dan sifat termalnya. Karakterisasi gugus fungsi poliuretan dilakukan dengan teknik spektrofotometri FTIR, sifat termalnya diukur dengan teknik Differential Thermal Analysis (DTA), Differential Scanning Calorimetry (DSC), dan Thermal Gravimetric Analysis (TGA). Penambahan sakarida (glukosa, maltosa) dan amilosa dalam sintesis poliuretan dapat meningkatkan besarnya indeks ikatan hidrogen (HBI) dan temperatur transisi gelas (Tg) poliuretan. Dengan semakin bertambahnya unit ulang glukosa penyusun poliol semakin meningkatkan besarnya indeks ikatan hidrogen (HBI), temperatur transisi gelas (Tg), serta kestabilan termal poliuretan.
\end{abstract}

Kata kunci: amilosa; DSC; DTA; FTIR; indeks ikatan hidrogen; poliuretan; sakarida; $T G A$.
Abstract. The properties of polyurethane depend largely on building blocks, especially the kind of polyol. Not only pure synthetic compounds but also various natural substances such as saccharides (glucose, fructose, maltose, sucrose) and amylose can be used as possible resources of polyol in polyurethane synthesis. Those natural substances are natural polymeric materials having appropriate reactivity thank to its functional groups such as hydroxyl groups. Natural polymers having more than two hydroxyl groups per molecule can be used as polyols for polyurethane synthesis. In this study, the effect of addition of saccharide (glucose, maltose) and amylose in the synthesis polyethylene glycol 400 (PEG400) and methylene-4,4'-diphenyldiisocyanate (MDI) based 
polyurethane was studied by measuring the hydrogen bonding index (HBI) and the thermal properties. Characterization of functional groups in resultant polyurethane was analyzed by FTIR spectrophotometry, the thermal properties were conducted with Differential Thermal Analysis (DTA), Differential Scanning Calorimetry (DSC), and Thermal Gravimetric Analysis (TGA). The addition of saccharide (glucose, maltose) and amylose on the synthesis polyurethane from polyethylene glycol 400 (PEG400) and methylene-4,4'diphenyldiisocyanate (MDI) can increase the hydrogen bonding index and the glass transition temperature of polyurethane. In all case the increase of glucose unit in polyol can increase the hydrogen bonding index, the glass transition temperature, and the thermal stability of polyurethane.

Keywords: amylose; DSC; DTA; FTIR; hydrogen bonding index; polyurethane; saccharide; $T G A$.

\section{$1 \quad$ Pendahuluan}

Konsumsi bahan polimer poliuretan khususnya di Indonesia setiap tahunnya mengalami peningkatan, terutama karena digunakan pada berbagai komponen kendaraan yang meliputi bagian eksterior dan interior misalnya bumper, panelpanel body, tempat duduk, dan lain-lain. Di bidang kedokteran, poliuretan digunakan sebagai bahan pelindung muka, kantung darah, dan lain-lain. Selain itu poliuretan telah digunakan pula untuk furniture, bangunan dan konstruksi, insulasi tank dan pipa, pabrik pelapis, alat-alat olahraga, serta sebagai bahan pembungkus [1-3].

Poliuretan merupakan bahan polimer yang mengandung gugus fungsi uretan (-NHCOO-) dalam rantai utamanya. Gugus uretan terbentuk dari reaksi antara gugus isosianat dengan gugus hidroksil, seperti nampak dalam persamaan reaksi berikut:

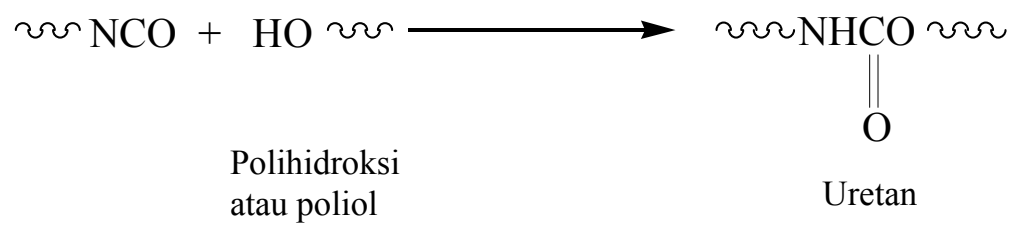

Pada awalnya banyak poliuretan yang dipatenkan adalah dari hasil reaksi diamin dan biskloroformat pada temperatur rendah. Setelah itu berkembang metoda polimerisasi lelehan (melt polymerization method) dan metoda larutan temperatur tinggi (high-temperature solution method) yang meliputi reaksi diisosianat dengan diol. Metoda yang meliputi reaksi diisosianat dengan diol berkembang lebih pesat melebihi metoda biskloroformat-diamin karena lebih sederhana dan tidak menghasilkan produk samping [4]. 
Henrie Ulrich [5] dalam studinya mengenai poliol, melaporkan bahwa poliol polieter dan poliester biasa digunakan untuk sintesis poliuretan. Poliol polieter merupakan polimer berat molekul rendah yang diperoleh dari reaksi pembukaan cincin pada polimerisasi alkilen oksida. Poliol poliester diperoleh dari reaksi polimerisasi glikol dengan asam dikarboksilat. Jadi pada dasarnya, poliuretan dibuat dari reaksi polimerisasi antara monomer-monomer diisosianat dengan poliol polieter atau poliester [6].

S. Kim dkk [7] telah berhasil mensintesis kopolimer blok selulosa yang dapat terbiodegradasi melalui reaksi selulosa dengan diisosianat tanpa penambahan dan dengan penambahan polipropilen glikol (PPG). Kemudian H. Hatakeyama [8] dalam penelitiannya mengenai poliuretan yang biodegradable berasal dari tumbuhan, menunjukkan bahwa poliuretan dapat disintesis menggunakan komonomer berupa polimer alam yang dikenal sebagai lignoselulosa. Berbagai sumber tumbuhan seperti lignin kraft, lignin solvolisis, kopi, sakarida seperti glukosa, fruktosa, sukrosa, dan molasse dapat dibuat poliuretan lewat pencampuran dengan polietilen glikol (PEG) atau polipropilen glikol (PPG) dan direaksikan dengan difenilmetan diisosianat (MDI). S. Owen [9] telah dapat mensintesis poliuretan yang biodegradable dengan menggunakan poliol berupa poli-D,L-asam laktat dan direaksikan dengan pMDI (polimetilen polifenil poliisosianat). Eli $\mathrm{R}$ dkk [10] telah mengungkapkan pengaruh pati tapioka terhadap pembentukan poliuretan.

Dengan meninjau hasil-hasil penelitian yang telah dilakukan sebelumnya maka pada penelitian ini telah dilakukan sintesis poliuretan dari PEG400 (polietilen glikol 400) dan MDI (metilen-4,4'-difenildiisosianat) dengan menggunakan glukosa, maltosa, dan amilosa sebagai komonomernya. Adapun alasan penggunaan komonomer tersebut dalam sintesis poliuretan, yaitu karena struktur molekulnya memiliki tiga atau lebih gugus hidroksil bebas maka bahan tersebut dapat berfungsi sebagai poliol yang apabila direaksikan dengan diisosianat akan terbentuk poliuretan. Jadi tujuan dari penelitian ini adalah untuk mengetahui pengaruh penambahan komonomer glukosa, maltosa, dan amilosa terhadap pembentukan poliuretan dari PEG400 dan MDI.

\section{Bahan dan Metoda}

\subsection{Bahan}

Bahan-bahan kimia yang digunakan dalam sintesis poliuretan, yaitu:

i. Metilen-4,4'-difenildiisosianat (MDI) berupa cairan kental berwarna coklat dengan rumus struktur sebagai berikut:

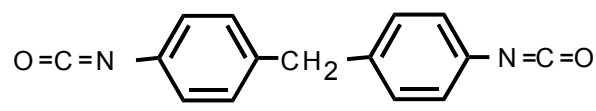


ii. Polietilenglikol (PEG) berat molekul 400 berupa cairan kental tak berwarna dengan rumus struktur sebagai berikut:

$$
\mathrm{HO}-\left(\mathrm{CH}_{2} \mathrm{CH}_{2} \mathrm{O}\right)_{n}-\mathrm{H}
$$

iii. Glukosa berupa padatan putih dengan rumus struktur sebagai berikut:

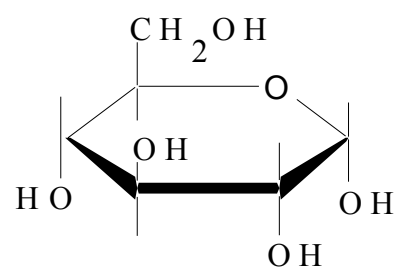

iv. Maltosa berupa padatan putih dengan rumus struktur sebagai berikut:

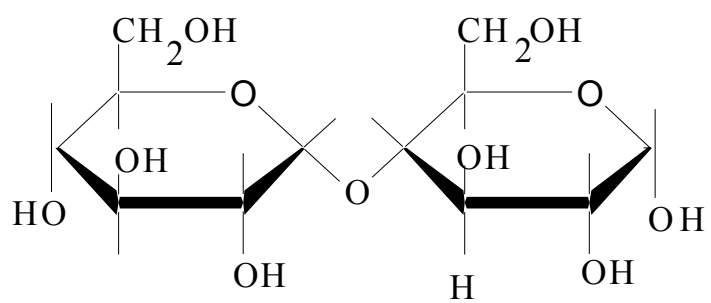

v. Amilosa berupa padatan putih dengan rumus struktur sebagai berikut:

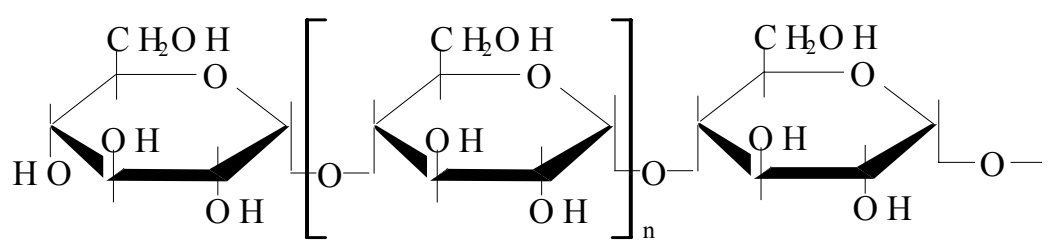

\subsection{Metoda}

\subsubsection{Reaksi Polimerisasi Pembentukan Poliuretan}

Pada tahap ini dilakukan reaksi polimerisasi pada temperatur kamar dengan perbandingan mol MDI/PEG adalah 1,0. Adapun variasi konsentrasi komonomer berupa poliol (glukosa, maltosa, dan amilosa) yang dipilih, yaitu: $5 \%$ (semuanya dalam $\% \mathrm{~b} / \mathrm{b}$ ) terhadap berat poliol dan PEG yang digunakan dalam sintesis poliuretan. Poliol (glukosa, maltosa, dan amilosa), PEG, dan MDI dimasukkan ke dalam reaktor labu leher tiga, kemudian dilakukan pengadukan selama 30 menit sambil dialiri gas nitrogen sehingga diperoleh cairan kental. Selanjutnya cairan kental yang diperoleh dimasukkan ke dalam 
cetakan dan dibiarkan mengeras. Sampel poliuretan dimasukkan ke dalam vacuum oven selama 48 jam sebelum dikarakterisasi.

\subsubsection{Karakterisasi}

Adapun uji karakterisasi yang dilakukan untuk setiap produk polimer poliuretan yang diperoleh yaitu uji kualitatif untuk melihat puncak serapan dan menghitung besarnya indeks ikatan hidrogen (HBI) dengan teknik spektrokopi inframerah (IR) menggunakan alat FTIR Shimadzu seri 8501 dengan teknik pellet $\mathrm{KBr}$ untuk persiapan sampelnya. Tingkat kontribusi absorpsi gugus karbonil dalam ikatan hidrogen dinyatakan oleh indeks ikatan hidrogen (HBI = Hydrogen Bonding Index), yaitu perbandingan relatif dari absorbansi puncak karbonil berikatan hidrogen terhadap puncak karbonil bebas. Puncak serapan ulur $\mathrm{C}=\mathrm{O}$ berikatan hidrogen berpusat pada $1700 \mathrm{~cm}^{-1}$ dan puncak serapan ulur $\mathrm{C}=\mathrm{O}$ bebas berpusat pada $\sim 1720 \mathrm{~cm}^{-1}$.

Dilakukan pula uji sifat termal dengan alat DTA General V4.1C Du Pont 2000, DSC, dan TGA V5.1A.

\section{$3 \quad$ Hasil dan Diskusi}

\subsection{Hasil Reaksi Pembentukan Poliuretan}

\subsubsection{Spektrum FTIR}

Hasil karakterisasi terhadap poliuretan hasil sintesis dengan teknik spektroskopi FTIR menunjukkan pita serapan pada $3330 \mathrm{~cm}^{-1}$ yang merupakan daerah ulur $\mathrm{N}-\mathrm{H}, \sim 1730 \mathrm{~cm}^{-1}$ merupakan daerah serapan gugus uretan, $1720 \mathrm{~cm}^{-1}$ merupakan daerah serapan ulur $\mathrm{C}=\mathrm{O}$ bebas, $1700 \mathrm{~cm}^{-1}$ merupakan daerah serapan ulur $\mathrm{C}=\mathrm{O}$ yang berikatan hidrogen, $1541 \mathrm{~cm}^{-1}$ merupakan daerah serapan deformasi $\mathrm{N}-\mathrm{H}, 1400 \mathrm{~cm}^{-1}$ merupakan daerah serapan $\mathrm{C}-\mathrm{N}-\mathrm{C}$, dan $\sim 1100 \mathrm{~cm}^{-1}$ yang merupakan daerah serapan ulur C-O. Pembandingan spektrum FTIR poliuretan hasil sintesis dengan data referensi menunjukkan pita-pita serapan pada daerah yang hampir sama terutama pada daerah pita serapan karakteristik. Pada Gambar 1 tampak hasil spektrum FTIR poliuretan yang berasal dari PEG-MDI dan poliuretan yang berasal dari glukosa-PEG-MDI, maltosa-PEG-MDI, dan amilosa-PEG-MDI.

Berdasarkan hasil perhitungan besarnya indeks ikatan hidrogen (HBI) seperti yang nampak pada Tabel 1 menunjukkan bahwa dengan penambahan poliol (glukosa,maltosa, dan amilosa) dalam sintesis poliuretan dapat meningkatkan nilai HBI dari poliuretan, ini mengindikasikan bahwa derajat ikatan hidrogen dari gugus karbonil yang ada pada bagian interior hard segment meningkat dengan adanya penambahan komonomer berupa poliol tersebut. 


\begin{tabular}{|c|c|c|}
\hline No & $\begin{array}{c}\text { Jenis Poliol yang Ditambahkan dalam Sintesis } \\
\text { Poliuretan dari PEG400-MDI }\end{array}$ & $\begin{array}{c}\text { Nilai HBI (Hydrogen } \\
\text { Bonding Index) }\end{array}$ \\
\hline 1 & - & 0,23 \\
\hline 2 & Glukosa & 0,87 \\
\hline 3 & Maltosa & 2,01 \\
\hline 4 & Amilosa & 3,85 \\
\hline
\end{tabular}

Tabel 1 Hasil Penentuan Nilai HBI (Indeks Ikatan Hidrogen) Poliuretan.

Penambahan poliol berupa glukosa, maltosa, dan amilosa dalam sintesis poliuretan dapat meningkatkan antaraksi intermolekuler antara hard segment dengan hard segment yang ada dalam poliuretan. Menurut Huang [11], meningkatnya nilai HBI menunjukkan lebih banyak terjadinya antaraksi intermolekuler antara hard segment-hard segment dalam daerah hard segment untuk bergabung daripada terdispersinya hard segment dalam daerah soft segment.

\subsubsection{Sifat Termal}

Berdasarkan analisis kurva hasil pengukuran dengan teknik DSC (Differential Scanning Calorimetry) diperoleh hasil seperti yang tampak pada Tabel 2. Penambahan poliol dalam sintesis poliuretan dapat meningkatkan temperatur transisi gelas poliuretan. Perubahan nilai temperatur transisi gelas tersebut menunjukkan peningkatan yang cukup berarti. Sebagaimana telah diketahui bahwa glukosa, maltosa, dan amilosa masing-masing terdiri atas 1, 2, dan banyak unit ulang glukosa dalam molekulnya dan memiliki lebih dari dua gugus hidroksil dalam setiap unit ulangnya. Hal ini dapat menurunkan mobilitas rantai utama dari molekul poliuretan dan menyebabkan terjadinya peningkatan temperatur transisi gelas.

\begin{tabular}{|c|c|c|}
\hline No & $\begin{array}{c}\text { Jenis Poliol yang Ditambahkan dalam Sintesis } \\
\text { poliuretan dari PEG400-MDI }\end{array}$ & $\begin{array}{c}\text { Temperatur Transisi } \\
\text { Gelas }\left({ }^{\circ} \mathrm{C}\right)\end{array}$ \\
\hline 1 & - & 1,69 \\
\hline 2 & Glukosa & 2,35 \\
\hline 3 & Maltosa & 3,75 \\
\hline 4 & Amilosa & 10,97 \\
\hline
\end{tabular}

Tabel 2 Temperatur Transisi Gelas Poliuretan.

Hasil analisis sifat termal poliuretan dengan menggunakan teknik DTA (Differential Thermal Analysis) dapat dilihat pada Gambar 2. Dari kedua kurva tersebut nampak bahwa dengan penambahan poliol amilosa dalam sintesis poliuretan dari PEG400 dan MDI ternyata terjadi pergeseran peak endotermik 
ke arah nilai lebih kecil, yaitu dari $444,87^{\circ} \mathrm{C}$ menjadi $373,92^{\circ} \mathrm{C}$. Selanjutnya, penambahan amilosa dapat menurunkan temperatur degradasi poliuretan.

Hasil analisis sifat termal menggunakan teknik TGA (Thermal Gravimetric Analysis) menunjukkan bahwa poliuretan yang berasal dari PEG dan MDI mengalami dua tahap dekomposisi sedangkan poliuretan yang berasal dari poliol (glukosa, maltosa, dan amilosa), PEG, dan MDI mengalami tiga tahap dekomposisi (nampak pada Gambar 3). Pemeriksaan teliti kedua termogram tersebut menampakkan adanya perbedaan temperatur pada tahap akhir dekomposisi. Untuk poliuretan dari PEG-MDI dekomposisi mulai terjadi pada temperatur $450^{\circ} \mathrm{C}$, sedangkan untuk poliuretan dari poliol (glukosa, maltosa, dan amilosa)-PEG-MDI dekomposisi mulai pada $500^{\circ} \mathrm{C}$. Dengan demikian terjadi pergeseran temperatur dekomposisi dari poliuretan yang mengandung poliol ke nilai yang lebih tinggi. Ini menunjukkan bahwa penambahan poliol (glukosa, maltosa, dan amilosa) dalam sintesis poliuretan dapat meningkatkan kestabilan termal poliuretan.

Pada Tabel 3 disajikan persen kehilangan berat poliuretan yang berasal dari PEG-MDI dan dari poliol (glukosa, maltosa, amilosa)-PEG-MDI pada berbagai temperatur.

\begin{tabular}{|c|l|c|c|c|c|c|c|c|}
\hline \multirow{2}{*}{ No } & \multicolumn{1}{|c|}{ Sampel } & \multicolumn{7}{|c|}{ \%Kehilangan berat (\%) } \\
\cline { 3 - 9 } & & $100^{\circ} \mathrm{C}$ & $200^{\circ} \mathrm{C}$ & $300^{\circ} \mathrm{C}$ & $400^{\circ} \mathrm{C}$ & $500^{\circ} \mathrm{C}$ & $600^{\circ} \mathrm{C}$ & $700^{\circ} \mathrm{C}$ \\
\hline 1 & PU dari PEG-MDI & 6,76 & 7,35 & 15,00 & 57,00 & 64,12 & 86,00 & $*$ \\
\hline 2 & $\begin{array}{l}\text { PU dari glukosa- } \\
\text { PEG-MDI }\end{array}$ & 1,55 & 3,66 & 5,45 & 35,57 & 46,05 & 62,35 & 99,10 \\
\hline 3 & $\begin{array}{l}\text { PU dari maltosa- } \\
\text { PEG-MDI }\end{array}$ & 2,00 & 4,00 & 7,00 & 39,00 & 51,00 & 70,00 & 100,00 \\
\hline 4 & $\begin{array}{l}\text { PU dari amilosa } \\
\text { PEG-MDI }\end{array}$ & 5,00 & 7,10 & 10,00 & 45,59 & 63,00 & 81,47 & 96,77 \\
\hline
\end{tabular}

Tabel 3 Data \%Kehilangan Berat Poliuretan pada Berbagai Temperatur.

Keempat jenis poliuretan hasil sintesis menunjukkan nilai persen kehilangan berat yang kecil pada temperatur di bawah $300^{\circ} \mathrm{C}$. Pada setiap nilai temperatur, poliuretan yang berasal dari poliol (glukosa, maltosa, amilosa)-PEG-MDI memiliki nilai persen kehilangan berat lebih rendah dibandingkan dengan poliuretan yang berasal dari PEG-MDI. Pada temperatur $600^{\circ} \mathrm{C}$, persen kehilangan berat yang dialami poliuretan yang berasal dari glukosa-PEG-MDI adalah $62,35 \%$, poliuretan yang berasal dari maltosa-PEG-MDI $70 \%$, sedangkan poliuretan yang berasal dari PEG-MDI lebih besar persen kehilangan beratnya yaitu sebanyak $86 \%$. 


\section{$4 \quad$ Kesimpulan}

Penambahan poliol berupa glukosa, maltosa, dan amilosa dalam sintesis poliuretan dari metilen-4,4'-difenildiisosianat (MDI) dan polietilen glikol400 (PEG400) dapat meningkatkan nilai indeks ikatan hidrogen (HBI) dan temperatur transisi gelas poliuretan. Ini menunjukkan bahwa poliol (glukosa, maltosa, dan amilosa) berfungsi sebagai pembentuk hard segment dalam jaringan molekul poliuretan.

Penambahan komonomer poliol (glukosa, maltosa, dan amilosa) dalam sintesis poliuretan dapat meningkatkan kestabilan termal produk poliuretan.

\section{Ucapan Terima Kasih}

Terima kasih disampaikan kepada Direktorat Jenderal Pendidikan Tinggi, Departemen Pendidikan Nasional, atas bantuan dana melalui The University Research for Graduate Education (URGE).

\section{Daftar Pustaka}

1. Brydson, J. A., Plastic Materials, ed. 6, Butterworth Heinemann Ltd. (1995), $756-757$.

2. Kricheldorf, H. R., Poly(urethanes) and Related Polymers, dalam Eisenbach, C. D., A Handbook of Polymer Synthesis, Marcel Dekker, Inc. (1992), 685.

3. Hartomo, A. J., Dasar-Dasar Profesi Politeknik Pemrosesan Polimer Praktis, ed.1, Penerbit Andi Offset Yogyakarta (1993), 100.

4. Nicholson, J. W., The Chemistry of Polyme, edisi 2, The Royal Society of Chemistry, Cambridge (1997), 19, 71.

5. Ulrich, Henrie, Introduction to Industrial Polymers, Hanser Publishers, New York (1982), $83-88$.

6. Frisch, K. C. \& Kordomenos, P., Applied Polymer Chemistry, edisi 2, ACS Symposium Series 285, Washington DC (1985), 985 - 1021.

7. Schnabel, W., Polymer Degradation, Principles and Practical Applications, Macmillan Publishing Co, Inc., New York (1981), 154 176.

8. Hatakeyama, H., Hirose, S., Hatakyama, T., Nakamura, K., Kobashigawa, K. \& Morohoshi, N., Biodegradable Polyurethanes from Plant Component, J. Pure Applied Chemistry, A32(4), 743 - 750 (1995).

9. Owen, S., Masaoka, M., Kawamura, R. \& Sakota, N., Biodegradation of Poly-D, L-Lactic Acid Polyurethanes, Degradable Polymers, Recycling, and Plastics Waste Management, editor: Ann-Christine Albertsson and Samuel J. Huang, Marcel Dekker Inc., New York (1995), 81 - 85. 
Pengaruh Jenis Poliol terhadap Pembentukan Poliuretan 105

10. Rohaeti, E., Surdia, N. M., Radiman, C. L. \& Ratnaningsih, E., Thermal Properties of Synthesized Polyurethane with Tapioca Starch, Proceedings of The Second International Workshop on Green Polymers, Indonesian Polymer Association (2000), 313-316.

11. Huang, S. L., Structure-Tensile Properties of Polyurethanes, Eur. Polym.J., 33, 10-12, 1563-1567 (1997). 


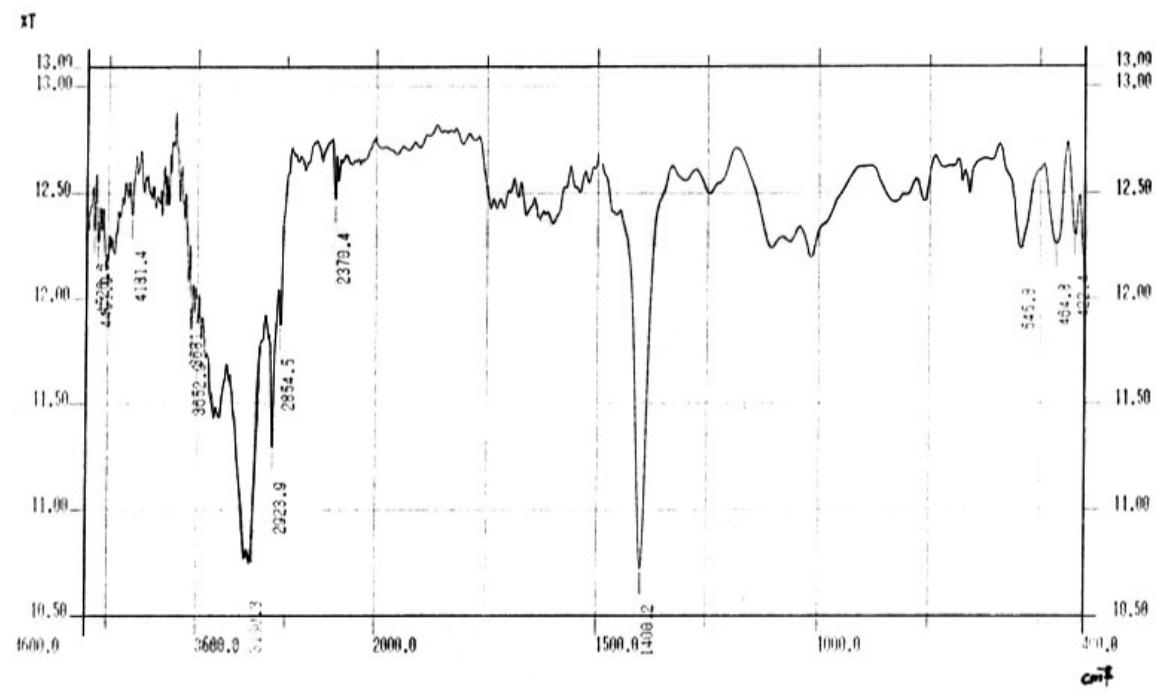

Gambar 1(a) Spektrum FTIR Poliuretan yang berasal dari PEG - MDI.

זT

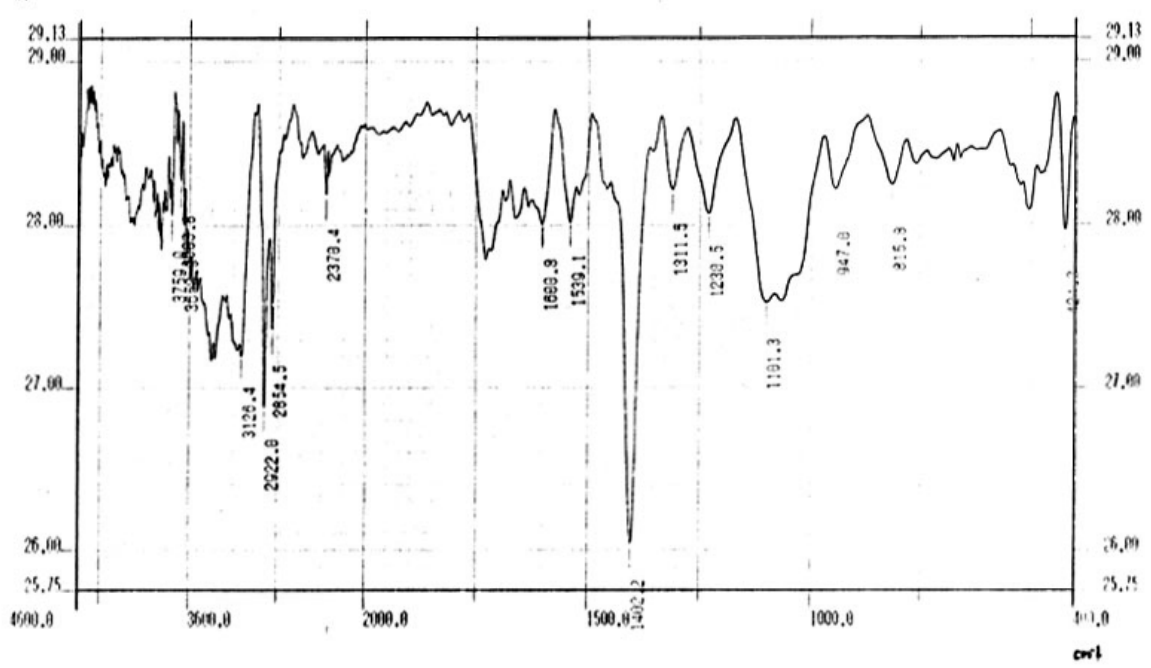

Gambar 1(b) Spektrum FTIR Poliuretan yang berasal dari Glukosa - PEG - MDI. 


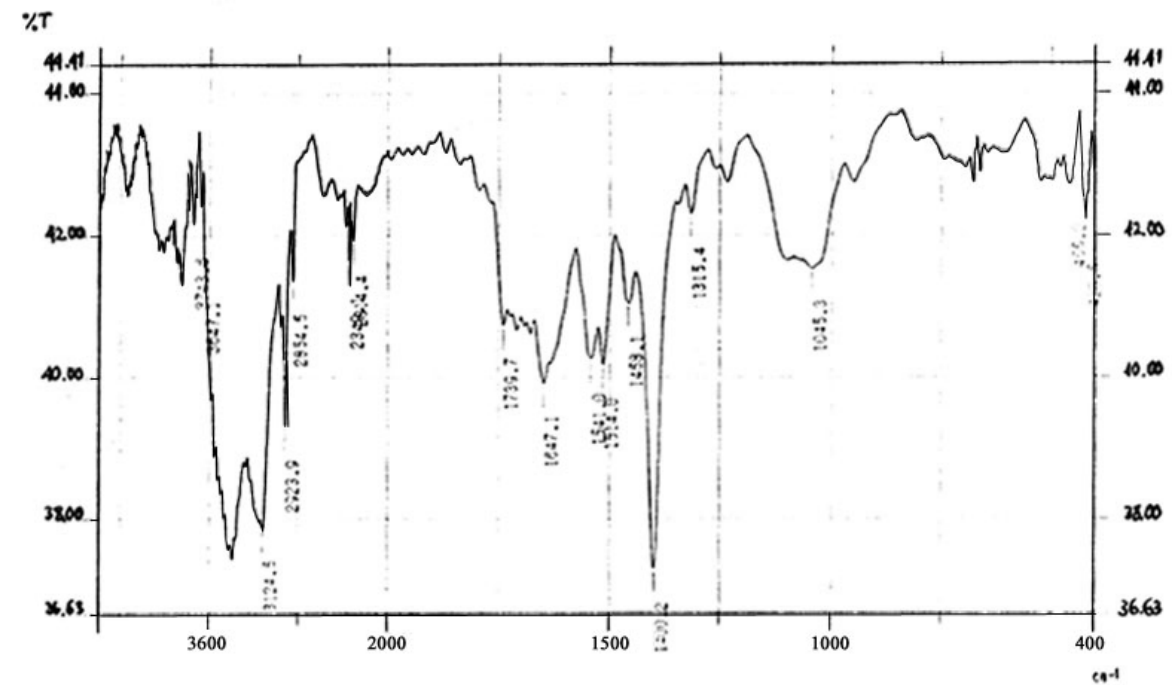

Gambar 1(c) Spektrum FTIR Poliuretan yang berasal dari Maltosa - PEG - MDI.

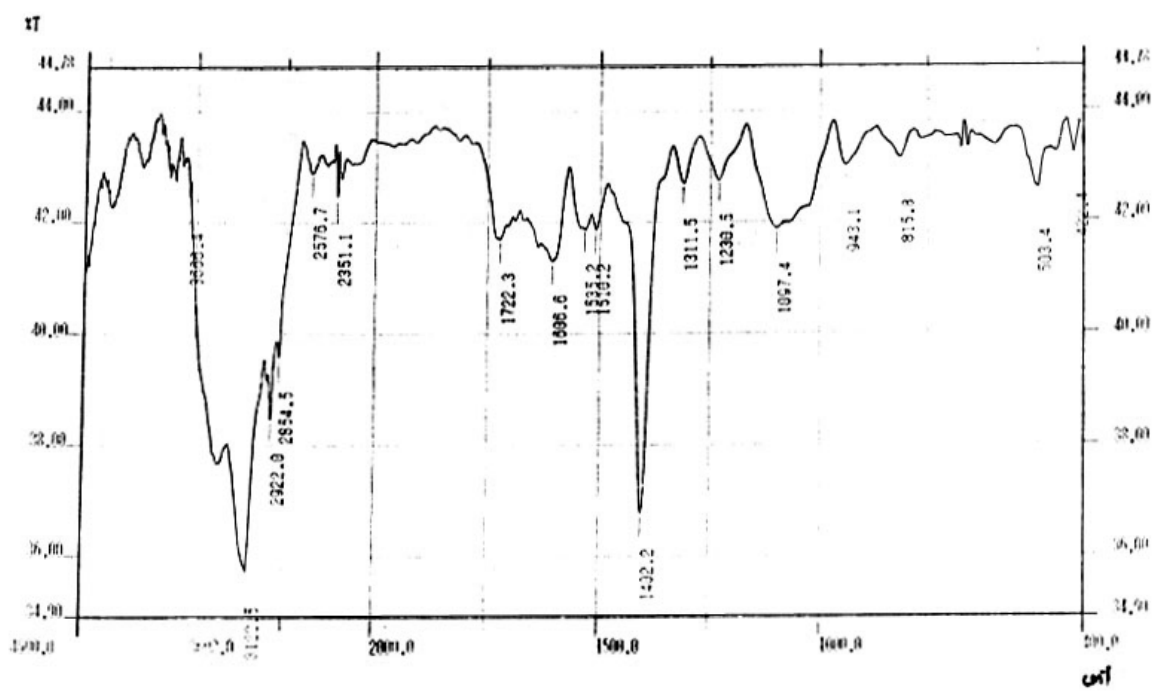

Gambar 1(d) Spektrum FTIR Poliuretan yang berasal dari Amilosa - PEG - MDI. 

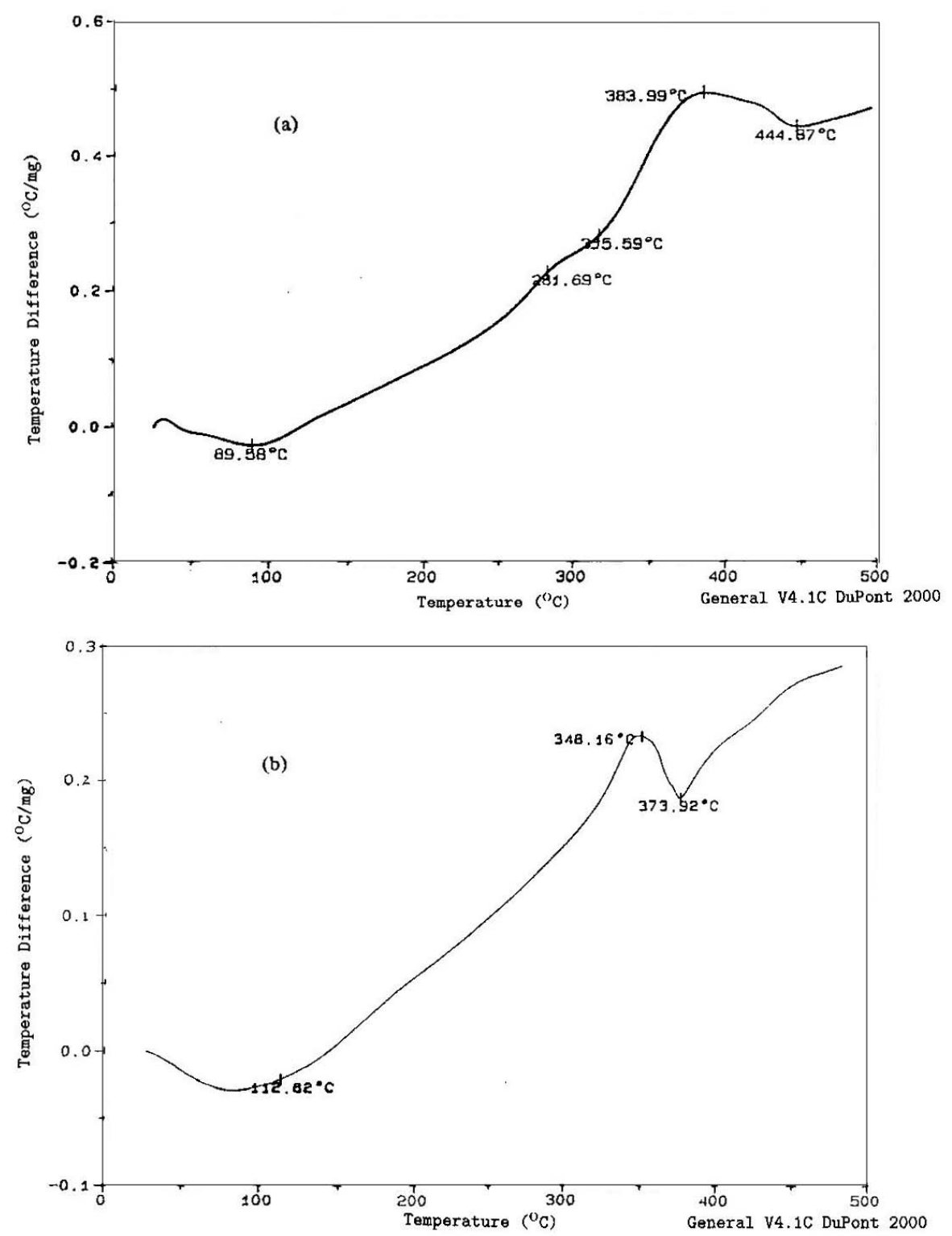

Gambar 2 Kurva DTA Poliuretan yang berasal dari (a) PEG - MDI

(b) Amilosa - PEG - MDI. 
Pengaruh Jenis Poliol terhadap Pembentukan Poliuretan 109

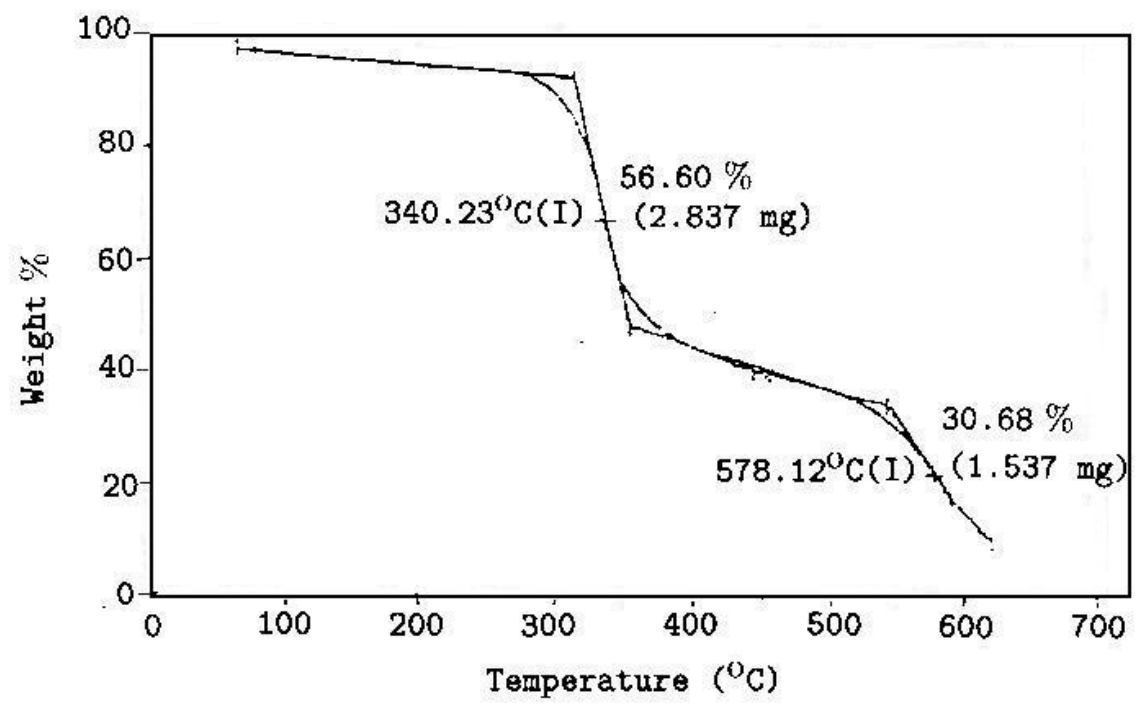

Gambar 3(a) Termogram Poliuretan yang berasal dari PEG - MDI.

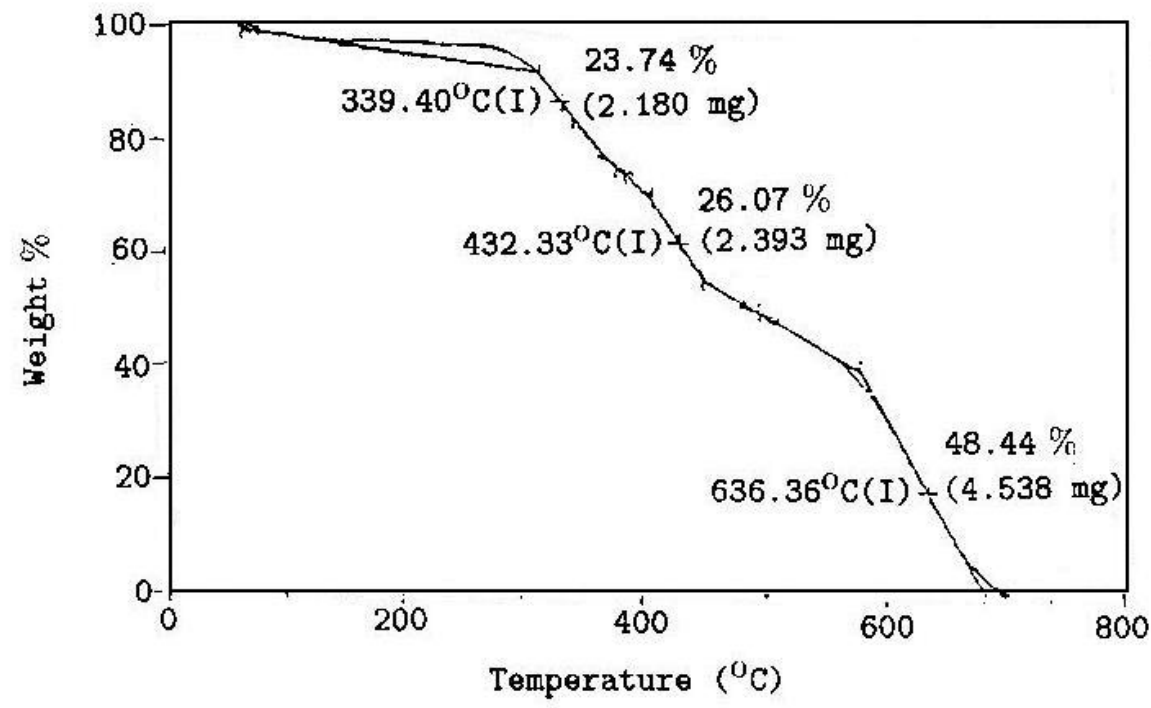

Gambar 3(b) Termogram Poliuretan yang berasal dari Maltosa - PEG - MDI. 